\section{Evaluation of second year dental students' perceptions on preclinical prosthodontic program}

\section{Diş hekimliği}

fakültesi ikinci sınıf öğrencilerinin protetik diş tedavisi preklinik dersi ile ilgili algılarının değerlendirilmesi

\section{Prof. İdil Dikbaş}

Yeditepe University, Faculty of Dentistry, Department of Prosthodontics, Istanbul, Turkey.

\section{Assoc. Prof. Zeynep Özkurt-Kayahan \\ Yeditepe University, Faculty of Dentistry,Department of Prosthodontics, Istanbul, Turkey.}

Prof. Dr. Fatma Ünalan

Istanbul University, Faculty of Dentistry,Department of Prosthodontics, Istanbul, Turkey.

Received : 23 October 2015

Accepted : 28 January 2016

\section{Corresponding author:}

Prof. Idil Dikbaş

Yeditepe University, Faculty of Dentistry

Department of Prosthodontics, Bağdat cad. No: 238

34728, Goztepe, Istanbul, Turkey

Tel: 02163606344

Fax: 02163636211

idil.dikbas@yeditepe.edu.tr

\section{SUMMARY}

Aim: The aim of this study was to obtain information among 2 dental schools in Turkey regarding preclinical students' perception, stress levels and preparedness for their future clinical studies.

Materials and methods: This study was conducted on the second year students in one foundation and one state dental school in Istanbul. The questionnaire consisted of questions about students' opinions about their stress levels in preclinical exercises of prosthodontics, as well as adequacy of knowledge they received from their preclinical training. Data were analyzed using the chi-square test.

Results: The students of the foundation school considered that feedback received from the instructors during laboratory exercises was highly satisfactory with statistically significant differences. In addition they regarded didactic knowledge received for preclinical exercises as highly satisfactory. In general, students of the foundation school felt themselves more prepared for treating patients with statistical significance.

Conclusions: Student's perceptions on preclinical prosthodontic educational program were different in foundation and state dental school. Dental school instructors must provide a well-established program for the students and educational curriculum must be regularly evaluated and updated to be beneficial for the dental student who is expected to start serving the public in the near future

Key words: dental education, prosthodontics, preclinic, student perception

ÖZET

Amaç: Bu çalışmanın amacl; Türkiye'de 2 farklı diş hekimliği fakültesindeki ikinci sınıf preklinik öğrencilerinin Protetik Diş Tedavisi dersi ile ilgili algıları, stres düzeyleri ve gelecek klinik çalışmalara hazırlıkı olmaları konusundaki bilgileri elde etmektir

Gereç ve Yöntem: Bu çalışma, biri devlet, diğeri vakıf üniversitesi diş hekimliği fakültelerinin ikinci sınıf preklinik öğrencileri üzerinde gerçekleştirilmiş̧tir. Öğrencilerin Protetik Diş Tedavisi preklinik uygulamaları esnasındaki stres düzeyleri ve kazandıkları bilgilerin yeterliliği konusundaki düşüncelerini almak için bir anket formu uygulanmışıır. Verilerin istatistiksel olarak değerlendirilmesinde ki-kare testi kullanılmışıtır.

Bulgular: Vakıf üniversitesi öğrencileri laboratuvar çalışmaları sırasında eğitmenlerden aldıkları geri bildirimlerin oldukça yeterli olduğunu bildirmişlerdir. Ayrıca, aynı ögrenciler preklinik çalıșmaları için verilen teorik bilginin de anlamlı derecede farklıkla yeterli olduğunu 
vurgulamışlardır. Genel olarak değerlendirildiğinde, vakıf üniversitesi oğrencilerinin, devlet üniversitesi ögrencilerine oranla klinikte hasta bakımına anlamlı derecede farkılıkla daha hazır olduğu sonucu belirlenmiştir.

Sonuç: Vakıf ve devlet üniversitesi öğrencilerinin protetik diş tedavisi preklinik programı ile ilgili görüşleri farklılıklar göstermektedir. Eğitmenler ögrencilere sağlam temellere dayalı bir program oluşturmalı ve müfredat düzenli olarak değerlendirilerek yakın gelecekte topluma hizmet edecek olan diş hekimliği öğrencilerinin avantajına uygun şekilde güncellenmelidir.

Anahtar kelimeler: Eğitim, protetik diş tedavisi, preklinik, öğrenci algısı

\section{INTRODUCTION}

Prosthodontics is one of the indispensable elements of dental sciences and is expected to remain so due to the high demand in the population for this type of treatment approach. In spite of some presumptions among prosthodontists and dental educators regarding decline in edentulism in the upcoming years, a report by Douglass and Watson indicated a growing need for prosthodontic services until the year 2020 owing to the increase in the US population as well as life expectancy'. Although this prediction cannot be generalized to other populations, it can still be assumed that factors such as increasing life expectancy and the desire of individuals to lead a qualified lifestyle, brings along the necessity of provision of good function, esthetics and phonetics, which are issues directly related with the science of prosthodontics. Therefore, the importance of knowledge and skills in treating edentulous patients will continue ${ }^{2}$ and predoctoral prosthodontic programs are still necessary to meet the dental therapeutic needs of the society ${ }^{3}$. Since prosthodontics comprises a very significant proportion of contemporary dental health services, dental school authorities as well as prosthodontics instructors and staff must spend utmost effort to provide a well-established program for the student.

One of the essential components of prosthodontic training is the preclinical portion of the curriculum. During preclinical exercises, students acquire and develop their fundamental dental skills, improve their tactile abilities and gain knowledge about the laboratory aspects of the prosthodontic sciences. Traditionally, the first and second year of the dental education program is dedicated to this phase of prosthodontics training. However; preclinical studies have been criticized by some indicating that teaching dental students clinical procedures in the laboratory setting requires that students gain an abstract understanding of the process of denture fabrication, rather than creating a process that involves alternating sequences of clinical and laboratory procedures found in clinical practice ${ }^{4}$.

In the literature, it has been stated that dental students have considerable stress during their education and they are more anxious than the general population ${ }^{5-7}$. It has been suggested that stress negatively affects their physical and mental health, therefore interfere with their performance during dental procedures ${ }^{8}$. A survey of the literature also reveals that there is yet no study performed so far that focuses on the perceptions and feedback of dental students regarding their preclinical education in Turkey. The purpose of this study was to obtain information regarding preclinical students' perception, stress levels and preparedness for their future clinical studies. Meanwhile, the survey was conducted among 2 dental schools in Istanbul to assess whether any difference existed between the feedbacks received from different students in different institutions.

\section{MATERIALS and METHODS}

This study was conducted on the second year students enrolled in one foundation (Yeditepe University, Faculty of Dentistry) and one state dental school (Istanbul University, Faculty of Dentistry) in Istanbul, Turkey. The questionnaire created and used by Sukotjo et. al. ${ }^{9}$ was used for obtaining data after receiving permission from the author. The questionnaire was translated into Turkish language by a translator with a high-level of English translation skills who had more than 10 years of clinical and academic experience. It was stated at the beginning of the questionnaire that all data collected would be kept strictly confidential and the anonymity of the participant students was ensured. The questionnaire was then applied on 30 students (from Yeditepe University) twice for one week for the validity and reliability. In the statistical analyses, the Cronbach's alpha value was 0.895 for fixed prosthodontics, 0.727 for complete dentures and 0.850 for removable partial dentures. In addition, the Cohen's kappa coefficients were greater than 0.7 for each question, and it was determined that the questionnaire was valid and reliable.

Following institutional ethic committee approval, anonymous questionnaire forms were distributed to 48 second year students of the foundation school and 171 second year students of the state school a few weeks prior to the completion of the academic year, during the last course before the final exam. The survey lasted through the course hour. Prior to filling out the forms, students were informed that they were not obliged to complete and return the questionnaire and the process had no relationship with academic performance or grading. It was stated at 
the beginning of the questionnaire that all data collected would be kept strictly confidential and the anonymity of the participants was ensured.

The questionnaire consisted of 9 questions about their opinions regarding their stress levels in preclinical exercises as well as adequacy of knowledge they received from their preclinical training. Questions were generally directed on students' self-assessment of their preparedness in terms of clinical practices and hand-skills. The first 8 questions were multiple-choice with 3 answer options and students were asked to make scorings in fixed, removable and complete dentures, individually. The 9th question was open ended and inquired about students' personal opinion and suggestions for the improvement of the preclinical prosthodontic courses.

Before the statistical analyses, the state school sample size (n: 171) was randomly reduced (1 selected and 2 unselected) in order to become closer to foundation school's sample size (n: 48). Thus, the sample size belonging to the state school was decreased to 57. Percentages were obtained with respect to each question and comparable data was statistically analyzed using the chi-square test. The significance was set at $p<0.05$.

\section{RESULTS}

All the students responded to the questionnaire with a response rate of 100\%. One hundred and twenty-eight of the students (58.4\%) were females and ninety-one (41.6\%) were males. Results regarding students' answers to questions on complete dentures are presented in Table 1. The scoring "not stressful" was given with a significantly higher prevalence $(p<0.01)$ by the students of the foundation school (33.3\%) compared to the state school (7\%). The students (22.9\%) in the foundation school considered that they have more

\begin{tabular}{|c|c|c|c|c|}
\hline Complete Denture & & $\begin{array}{l}\text { state } \\
\text { university } \\
(\mathrm{n}=57) \\
\mathrm{n}(\%)\end{array}$ & $\begin{array}{l}\text { foundation } \\
\text { university } \\
(n=48) \\
n(\%)\end{array}$ & $p$ \\
\hline $\begin{array}{l}\text { How would you rate your level of stress } \\
\text { during the laboratory exercises? }\end{array}$ & $\begin{array}{l}\text { Not stressful } \\
\text { Stressful } \\
\text { Very stressful }\end{array}$ & $\begin{array}{l}4(7.0 \%) \\
35(61.4 \%) \\
18(31.6 \%)\end{array}$ & $\begin{array}{l}16(33.3 \%) \\
27(56.3 \%) \\
5(10.4 \%)\end{array}$ & $0.001 * *$ \\
\hline $\begin{array}{l}\text { What do you think about the duration of the } \\
\text { laboratory exercises? }\end{array}$ & $\begin{array}{l}\text { Too short } \\
\text { Just right } \\
\text { Too long }\end{array}$ & $\begin{array}{l}1(1.8 \%) \\
47(82.5 \%) \\
9(15.8 \%)\end{array}$ & $\begin{array}{l}1(2.1 \%) \\
43(89.6 \%) \\
4(8.3 \%)\end{array}$ & 0.512 \\
\hline $\begin{array}{l}\text { Do you think you have enough input/ } \\
\text { feedback on your laboratory work from your } \\
\text { instructors during laboratory exercises? }\end{array}$ & $\begin{array}{l}\text { Not enough } \\
\text { Just right } \\
\text { More than enough }\end{array}$ & $\begin{array}{l}12(21.1 \%) \\
43(75.4 \%) \\
2(3.5 \%)\end{array}$ & $\begin{array}{l}7(14.6 \%) \\
30(62.5 \%) \\
11(22.9 \%)\end{array}$ & $0.01 *$ \\
\hline $\begin{array}{l}\text { Do you feel the knowledge you have gained } \\
\text { from the lecture is adequate for laboratory } \\
\text { exercises? }\end{array}$ & $\begin{array}{l}\text { Not adequate } \\
\text { Just right } \\
\text { More than adequate }\end{array}$ & $\begin{array}{l}4(7.0 \%) \\
51(89.5 \%) \\
2(3.5 \%)\end{array}$ & $\begin{array}{l}7(14.6 \%) \\
32(66.7 \%) \\
9(18.8 \%)\end{array}$ & $0.012 \star$ \\
\hline $\begin{array}{l}\text { Do you think the knowledge you obtained } \\
\text { from the lectures is helpful in preparing for } \\
\text { clinical practice? }\end{array}$ & $\begin{array}{l}\text { Yes } \\
\text { No } \\
\text { Not certain }\end{array}$ & $\begin{array}{l}18(31.6 \%) \\
13(22.8 \%) \\
26(45.6 \%)\end{array}$ & $\begin{array}{l}30(62.5 \%) \\
5(10.4 \%) \\
13(27.1 \%)\end{array}$ & $0.006 * *$ \\
\hline $\begin{array}{l}\text { How prepared (from your pre-clinical } \\
\text { experiences) do you feel about treating } \\
\text { patients in the clinic? (self-confidence) }\end{array}$ & $\begin{array}{l}\text { Unprepared } \\
\text { Just right } \\
\text { Well prepared }\end{array}$ & $\begin{array}{l}36(63.2 \%) \\
17(29.8 \%) \\
4(7.0 \%)\end{array}$ & $\begin{array}{l}16(33.3 \%) \\
27(56.3 \%) \\
5(10.4 \%)\end{array}$ & $0.009 * *$ \\
\hline $\begin{array}{l}\text { Do you think you have enough clinical-skill } \\
\text { (hand-skill) training to treat patients in the } \\
\text { clinic? }\end{array}$ & $\begin{array}{l}\text { Not enough } \\
\text { Just right } \\
\text { More than enough }\end{array}$ & $\begin{array}{l}26(45.6 \%) \\
27(47.4 \%) \\
4(7.0 \%)\end{array}$ & $\begin{array}{l}13(27.1 \%) \\
29(60.4 \%) \\
6(12.5 \%)\end{array}$ & 0.131 \\
\hline $\begin{array}{l}\text { How helpful are tutorials or PBL in helping } \\
\text { you understand pre-clinical and clinical } \\
\text { knowledge and skills? }\end{array}$ & $\begin{array}{l}\text { Not helpful } \\
\text { Helpful } \\
\text { Very helpful }\end{array}$ & $\begin{array}{l}1(1.8 \%) \\
55(96.5 \%) \\
1(1.8 \%)\end{array}$ & $\begin{array}{l}3(6.3 \%) \\
35(72.9 \%) \\
10(20.8 \%)\end{array}$ & $0.002 * *$ \\
\hline Chi-square test was used & \multicolumn{2}{|l|}{$* p<0.05$} & \multicolumn{2}{|l|}{$\star * \mathrm{p}<0.01$} \\
\hline
\end{tabular}

Table 1: Evaluation of the answers on complete dentures 
than enough input/feedback on their laboratory work from their instructors during laboratory exercises, and this rate was significantly higher $(p<0.05)$ than the state school students (3.5\%). In addition, the students of the foundation school (18.8\%) found the knowledge received from didactic training for preclinical exercises more than adequate with a significantly higher difference $(p<0.05)$ compared to the state school (3.5\%). When the scores of the question asking the knowledge they obtained from the lectures is helpful in preparing for clinical practice, the students of the foundation school (62.5\%) regarded this parameter helpful with a significantly higher difference $(p<0.01)$ compared to the state school (31.6\%). On the other hand the students (63.2\%) belonging to the state school stated that they feel unprepared about treating patients in the clinic, with a significant difference $(p<0.01)$ compared to the foundation school (33.3\%). The students of the foundation school (20.8\%) found tutorials or problem based learning (PBL) in helping them understand pre-clinical and clinical knowledge and skills very helpful with a statistically higher difference $(p<0.01)$ compared to the state school (1.8\%)

The distribution of the answers to each question on removable partial dentures is presented in Table 2. The students (31.6\%) belonging to the state school considered that they were very stressful with a significant difference $(p<0.01)$ compared to the foundation school (8.3\%). When the scores of the question asking the adequacy of the knowledge received from didactic training for preclinical exercises were evaluated, the students of the foundation school (20.8\%) regarded this parameter more than adequate with a significantly higher difference $(p<0.05)$ compared to the state school (3.5\%). On the other hand, the results of the question asking whether the knowledge obtained from lectures is helpful in preparing for clinical practice revealed that the students of the foundation school answers (56.3\%) were positive with a significantly higher difference $(p<0.05)$ compared to the state school (29.8\%). Finally, the

\begin{tabular}{|c|c|c|c|c|}
\hline Removable Partial Denture & & $\begin{array}{l}\text { state university } \\
(\mathrm{n}=57) \\
\mathrm{n}(\%)\end{array}$ & $\begin{array}{l}\text { foundation } \\
\text { university }(n=48) \\
n(\%)\end{array}$ & $p$ \\
\hline $\begin{array}{l}\text { How would you rate your level of stress } \\
\text { during the laboratory exercises? }\end{array}$ & $\begin{array}{l}\text { Not stressful } \\
\text { Stressful } \\
\text { Very stressful }\end{array}$ & $\begin{array}{l}7(12.3 \%) \\
32(56.1 \%) \\
18(31.6 \%)\end{array}$ & $\begin{array}{l}16(33.3 \%) \\
28(58.3 \%) \\
4(8.3 \%)\end{array}$ & $0.002 * *$ \\
\hline $\begin{array}{l}\text { What do you think about the duration of the } \\
\text { laboratory exercises? }\end{array}$ & $\begin{array}{l}\text { Too short } \\
\text { Just right } \\
\text { Too long }\end{array}$ & $\begin{array}{l}2(3.5 \%) \\
48(84.2 \%) \\
7(12.3 \%)\end{array}$ & $\begin{array}{l}3(6.3 \%) \\
41(85.4 \%) \\
4(8.3 \%)\end{array}$ & 0.669 \\
\hline $\begin{array}{l}\text { Do you think you have enough input/ } \\
\text { feedback on your laboratory work } \\
\text { from your instructors during laboratory } \\
\text { exercises? }\end{array}$ & $\begin{array}{l}\text { Not enough } \\
\text { Just right } \\
\text { More than enough }\end{array}$ & $\begin{array}{l}15(26.3 \%) \\
38(66.7 \%) \\
4(7.0 \%)\end{array}$ & $\begin{array}{l}10(20.8 \%) \\
30(62.5 \%) \\
8(16.7 \%)\end{array}$ & 0.283 \\
\hline $\begin{array}{l}\text { Do you feel the knowledge you have gained } \\
\text { from the lecture is adequate for laboratory } \\
\text { exercises? }\end{array}$ & $\begin{array}{l}\text { Not adequate } \\
\text { Just right } \\
\text { More than adequate }\end{array}$ & $\begin{array}{l}9(15.8 \%) \\
46(80.7 \%) \\
2(3.5 \%)\end{array}$ & $\begin{array}{l}10(20.8 \%) \\
28(58.3 \%) \\
10(20.8 \%)\end{array}$ & $0.011 *$ \\
\hline $\begin{array}{l}\text { Do you think the knowledge you obtained } \\
\text { from the lectures is helpful in preparing for } \\
\text { clinical practice? }\end{array}$ & $\begin{array}{l}\text { Yes } \\
\text { No } \\
\text { Not certain }\end{array}$ & $\begin{array}{l}17(29.8 \%) \\
14(24.6 \%) \\
26(45.6 \%)\end{array}$ & $\begin{array}{l}27(56.3 \%) \\
6(12.5 \%) \\
15(31.3 \%)\end{array}$ & $0.021 *$ \\
\hline $\begin{array}{l}\text { How prepared (from your pre-clinical } \\
\text { experiences) do you feel about treating } \\
\text { patients in the clinic? (self-confidence) }\end{array}$ & $\begin{array}{l}\text { Unprepared } \\
\text { Just right } \\
\text { Well prepared }\end{array}$ & $\begin{array}{l}38(66.7 \%) \\
16(28.1 \%) \\
3(5.3 \%)\end{array}$ & $\begin{array}{l}23(47.9 \%) \\
21(43.8 \%) \\
4(8.3 \%)\end{array}$ & 0.152 \\
\hline $\begin{array}{l}\text { Do you think you have enough clinical-skill } \\
\text { (hand-skill) training to treat patients in the } \\
\text { clinic? }\end{array}$ & $\begin{array}{l}\text { Not enough } \\
\text { Just right } \\
\text { More than enough }\end{array}$ & $\begin{array}{l}28(49.1 \%) \\
27(47.4 \%) \\
2(3.5 \%)\end{array}$ & $\begin{array}{l}15(31.3 \%) \\
30(62.5 \%) \\
3(6.3 \%)\end{array}$ & 0.170 \\
\hline $\begin{array}{l}\text { How helpful are tutorials or PBL in helping } \\
\text { you understand pre-clinical and clinical } \\
\text { knowledge and skills? }\end{array}$ & $\begin{array}{l}\text { Not helpful } \\
\text { Helpful } \\
\text { Very helpful }\end{array}$ & $\begin{array}{l}2(3.5 \%) \\
54(94.7 \%) \\
1(1.8 \%)\end{array}$ & $\begin{array}{l}4(8.3 \%) \\
35(72.9 \%) \\
9(18.8 \%)\end{array}$ & $0.005 * *$ \\
\hline Chi-square test was used & \multicolumn{2}{|l|}{$\star p<0.05$} & \multicolumn{2}{|l|}{$* * \mathrm{p}<0.01$} \\
\hline
\end{tabular}

Table 2: Evaluation of the answers on removable partial dentures 
students of the foundation school (18.8\%) found tutorials or PBL in helping them understand pre-clinical and clinical knowledge and skills very helpful with a statistically higher difference ( $p<0.01)$ compared to the state school (1.8\%).

Table 3 shows the distribution of the answers given by students to each question on fixed prosthodontics. The students (38.6\%) belonging to the state school considered the time devoted to preclinical studies too long with a significant difference $(p<0.05)$ compared to the foundation school (16.7\%). When the scores of the question asking the adequacy of the knowledge received from didactic training for preclinical exercises were evaluated, the students of the foundation school (20.8\%) regarded this parameter more than adequate with a significantly higher difference $(p<0.05)$ compared to the state school (5.3\%). On the other hand, the results of the question asking whether the knowledge obtained from lectures is helpful in preparing for clinical practice revealed that the students of the foundation school answers (58.3\%) were positive with a significantly higher difference $(p<0.05)$ compared to the state school $(31.6 \%)$. Furthermore; the students of the foundation school (22.9\%) found tutorials or PBL in helping them understand preclinical and clinical knowledge and skills very helpful with a statistically higher difference $(p<0.01)$ compared to the state school (1.8\%)

The most frequent responses to the open-ended question were as follows: increasing the laboratory period, more helpful and gentle assistants, permission for the clinical observation, increasing demonstrations and laboratory works, using cheaper materials and natural teeth.

\begin{tabular}{|c|c|c|c|c|}
\hline Fixed Prosthodontics & & $\begin{array}{l}\text { state } \\
\text { university } \\
(\mathrm{n}=57) \\
\mathrm{n}(\%)\end{array}$ & $\begin{array}{l}\text { foundation } \\
\text { university } \\
\text { ( } \mathrm{n}=48) \\
\mathrm{n}(\%)\end{array}$ & $\mathrm{p}$ \\
\hline $\begin{array}{l}\text { 1. How would you rate your level of stress during the } \\
\text { laboratory exercises? }\end{array}$ & $\begin{array}{l}\text { Not stressful } \\
\text { Stressful } \\
\text { Very stressful }\end{array}$ & $\begin{array}{l}11(19.3 \%) \\
32(56.1 \%) \\
14(24.6 \%)\end{array}$ & $\begin{array}{l}18(37.5 \%) \\
23(47.9 \%) \\
7(14.6 \%)\end{array}$ & 0.093 \\
\hline $\begin{array}{l}\text { 2. What do you think about the duration of the laboratory } \\
\text { exercises? }\end{array}$ & $\begin{array}{l}\text { Too short } \\
\text { Just right } \\
\text { Too long }\end{array}$ & $\begin{array}{l}1(1.8 \%) \\
34(59.6 \%) \\
22(38.6 \%)\end{array}$ & $\begin{array}{l}3(6.3 \%) \\
37(77.1 \%) \\
8(16.7 \%)\end{array}$ & 0.031 * \\
\hline $\begin{array}{l}\text { 3. Do you think you have enough input/feedback on your } \\
\text { laboratory work from your instructors during laboratory } \\
\text { exercises? }\end{array}$ & $\begin{array}{l}\text { Not enough } \\
\text { Just right } \\
\text { More than enough }\end{array}$ & $\begin{array}{l}11(19.3 \%) \\
36(63.2 \%) \\
10(17.5 \%)\end{array}$ & $\begin{array}{l}8(16.7 \%) \\
32(66.7 \%) \\
8(16.7 \%)\end{array}$ & 0.923 \\
\hline $\begin{array}{l}\text { 4. Do you feel the knowledge you have gained from the } \\
\text { lecture is adequate for laboratory exercises? }\end{array}$ & $\begin{array}{l}\text { Not adequate } \\
\text { Just right } \\
\text { More than adequate }\end{array}$ & $\begin{array}{l}9(15.8 \%) \\
45(78.9 \%) \\
3(5.3 \%)\end{array}$ & $\begin{array}{l}8(16.7 \%) \\
30(62.5 \%) \\
10(20.8 \%)\end{array}$ & 0.047 * \\
\hline $\begin{array}{l}\text { 5. Do you think the knowledge you obtained from the } \\
\text { lectures is helpful in preparing for clinical practice? }\end{array}$ & $\begin{array}{l}\text { Yes } \\
\text { No } \\
\text { Not certain }\end{array}$ & $\begin{array}{l}18(31.6 \%) \\
11(19.3 \%) \\
28(49.1 \%)\end{array}$ & $\begin{array}{l}28(58.3 \%) \\
7(14.6 \%) \\
13(27.1 \%)\end{array}$ & 0.020 * \\
\hline $\begin{array}{l}\text { 6. How prepared (from your pre-clinical experiences) } \\
\text { do you feel about treating patients in the clinic? (self- } \\
\text { confidence) }\end{array}$ & $\begin{array}{l}\text { Unprepared } \\
\text { Just right } \\
\text { Well prepared }\end{array}$ & $\begin{array}{l}31(54.4 \%) \\
21(36.8 \%) \\
5(8.8 \%)\end{array}$ & $\begin{array}{l}19(39.6 \%) \\
25(52.1 \%) \\
4(8.3 \%)\end{array}$ & 0.274 \\
\hline $\begin{array}{l}\text { 7. Do you think you have enough clinical-skill (hand-skill) } \\
\text { training to treat patients in the clinic? }\end{array}$ & $\begin{array}{l}\text { Not enough } \\
\text { Just right } \\
\text { More than enough }\end{array}$ & $\begin{array}{l}21(36.8 \%) \\
33(57.9 \%) \\
3(5.3 \%)\end{array}$ & $\begin{array}{l}17(35.4 \%) \\
27(56.3 \%) \\
4(8.3 \%)\end{array}$ & 0.821 \\
\hline $\begin{array}{l}\text { 8. How helpful are tutorials or PBL in helping you } \\
\text { understand pre-clinical and clinical knowledge and } \\
\text { skills? }\end{array}$ & $\begin{array}{l}\text { Not helpful } \\
\text { Helpful } \\
\text { Very helpful }\end{array}$ & $\begin{array}{l}4(7.0 \%) \\
52(91.2 \%) \\
1(1.8 \%)\end{array}$ & $\begin{array}{l}2(4.2 \%) \\
35(72.9 \%) \\
11(22.9 \%)\end{array}$ & $0.003 * *$ \\
\hline Chi-square test was used & \multicolumn{2}{|l|}{$* p<0.05$} & \multicolumn{2}{|l|}{$* * p<0.01$} \\
\hline
\end{tabular}

Table 3: Evaluation of the answers on fixed prostheses 


\section{DISCUSSION}

The traditional preclinical training is still an essential part of the prosthodontic curriculum including complete, removable partial and fixed partial dentures. Before entering clinic, all students should have sufficient knowledge (theoretical and training) of clinical procedures ${ }^{10}$ and they must pass preclinical courses in which they practice on models to be prepared for the clinic ${ }^{11}$

Performance assessment of students should be conducted in order to guide their learning ${ }^{12}$. There are various methods to measure student performance one of which is selfassessment recommended by educators ${ }^{13}$, because students should have a realistic sense of their own strengths and weakness ${ }^{14}$. Accurate self-assessment is an important attribute to develop in dental students ${ }^{13}$. The present study used a survey created by Sukotjo et.al. ${ }^{9}$ which evaluated preclinical students' perception, stress levels and preparedness for their future clinical studies regarding their preclinical education.

In the present study, majority of the students both in the foundation (48-59\%) and the state school (56-61\%) rated themselves "stressful" during the laboratory exercises of all prosthodontic works. These results are similar with the study conducted by Sukotjo et.al. ${ }^{9}$ in Harvard School of Dental Medicine (HSDM) (56-60\%). The scoring "not stressful" was given with a significantly higher prevalence by the students of the foundation school (33.3\%) compared to the state school (7\%). It is understandable that that students of the foundation school regarded themselves less stressful compared to their peers in the state school. This may depend on a variety of reasons. Firstly, the higher student population of the state school may negatively influence the instructor/ student ratio, resulting in insufficient time devoted by faculty staff to each individual student, leading to unpreparedness of the students for future clinical practice. This may create a lack of self-confidence in the student producing higher stress levels accompanying anxiety in a procedure on which he or she has no experience. Meanwhile, complete dentures are the first types of laboratory procedure a student is asked to perform in the preclinical environment. This lack of hand skills and laboratory experience plus the low number of instructive staff to respond their questions and needs and aid where necessary may be enough reasons for students to experience high stress levels. Possible remedies to resolve this issue may be the recruitment of a higher number of qualified staff members or the decrease of students admitted to dental schools. In addition, students may be provided with a stress management program during their education.
During their first and second years, students in dental school in Turkey learn preclinical didactic and laboratory exercises before clinical practice. Each student is required to attend preclinical prosthodontic courses for 112 hours (8 hours per week, 14 week) both in his/her first and second year in the state school. The training period consists of 2 hours lectures per week, each of which is followed by six hours of practice time. On the other hand, in the foundation school, each student is required to attend the preclinical prosthodontic courses for 77 hours (5.5 hours per week 14 week) in the first year, and 252 hours (9 hours per week 28 week) in the second year. This period consists of 1 hourlecture and 4.5 hours of practical studies per week in the first year, and 1 hour-lecture and 8 hours of practical studies per week in the second year. Most of the students (82-89\%) thought that the duration of the laboratory exercises was just right for complete and removable partial dentures both in the foundation and the state school. Similar results (70\%) were obtained in Sukotjo's study ${ }^{9}$. However, the students in the state school (38.6\%) considered the time devoted to fixed partial denture studies was too long with a significant difference compared to the foundation school (16.7\%). The reason for such a result might be the initiation of preclinical practices with complete and removable partial dentures during the inexperienced phase of their educational lives Fixed partial dentures may appear easier as they acquire more competence and their manipulative skills progress throughout the preclinical program; therefore they are likely to consider this period relatively longer. One possible solution to make the training period more tolerable for the student may be the dispersion of preclinical hours to different days of the week; thus decrease the period spent for each individual preclinical class without compromising the integrity of the educational program.

The students often ask their instructors to evaluate their laboratory works. If they receive enough and accurate feedback from the instructors concerning the quality of their laboratory works and how their work could be corrected, they would have improvement in technical skills during preclinical exercises ${ }^{15}$. In the present study, majority of the students stated that they received enough feedback from their instructors during laboratory exercises, although the students in the foundation school (22.9\%) considered that they have more than enough feedback on complete denture works and this rate is significantly higher than the state school students (3.5\%). Lower number of instructive staff to respond their questions and higher number of students in the state school may be the reason of this result Majority of the students (56\%) in HSDM stated that they had enough feedback, similarly ${ }^{9}$. 
In dental schools, students are provided lectures and demonstrations in the preclinical courses in order to gain knowledge, which is a critical component of clinical performance ${ }^{16}$. The laboratory exercises and the practice time focus on the concepts taught in the lectures ${ }^{17}$. In this study, the results of the question asking whether the knowledge obtained from lectures is helpful in preparing for clinical practice revealed that the students of the foundation school answers were positive with a significantly higher difference compared to the state school for all issues of prosthodontics. In addition, the students of the foundation school found the knowledge gained from lectures for preclinical exercises more than adequate with a significantly higher difference compared to the state school. An education control program for evaluation of students' work should be established to improve the quality of restorations ${ }^{18}$

In the present study, both the state and foundation schools have patient simulation clinics especially for fixed partial dentures, and the students belonging to the state school stated that they feel unprepared about treating patients in the clinic, with a significant difference compared to the foundation school for complete dentures, which is the first course of the prosthodontic curriculum in their first year. Lack of confidence is a significant element on the success of clinical performance that should be handled before the transition from the preclinical courses to clinical procedures.

The primary aim of the preclinical training is to provide students with manipulative skills for successful patient care5. After completion of preclinical restorative practices and passing the examinations, students enter the clinic $^{17}$. Almost half of the students in state and foundation schools thought that they had enough hand skill training to treat patients in the clinic.

The skill and experience of the instructors should be adequate in helping the students to understand preclinical and clinical knowledge and skills. In the present study, the students of the foundation school found tutorials or PBL in helping them understand pre-clinical and clinical knowledge and skills very helpful with a statistically higher difference compared to the state school. Majority of the students (63-66\%) in HSDM found that tutorials were helpful, similarly9. The higher student population, decrease in instructor/student ratio and insufficient time devoted by tutorials to each student may be the reason of this result.

It is noteworthy to discuss the limitations of the present study. The two dental schools included in this study may show variations in terms of financial sources, institutional circumstances, culture, discipline, physical environments and student features as well as faculty attitude. In fact, it was presumed that the results would be a reflection of the impact of these parameters; however, it is also true that a standardization is very difficult with this respect. On the other hand, stress factors may vary from school to school. A foundation school's atmosphere might offer more comfortable studying and practicing opportunities which might help decrease possible stress that students are likely to experience. A state school's limited facilities might aggravate the burden and stress level of students, specifically during preclinical years.

\section{CONCLUSIONS}

Thisisthefirststudyaboutstudents' perceptionson preclinical prosthodontic program conducted in Turkey. Measuring dental students' perceptions of their level of stress and selfconfidence during their preclinical years before entering the clinic may lead to improve the courses and laboratory conditions including the practice time, assistants, tutorials and lessons, and regulate the inadequate topics. According to results, it can be clearly observed that dental students are stressful and they do not feel themselves prepared for the clinic. Stress reduction or anxiety management programs advised by faculty administration may be applied to students. The authors suggest that this survey should be conducted in other Turkish dental schools to determine the overall country situation and to make comparison between them. 


\section{REFERENCES}

1. Douglass CW, Watson AJ. Future needs for fixed and removable partial dentures in the United States: J Prosthet Dent 2002; 87: 9-14.

2. Lang $B R$. A review of traditional therapies in complete dentures. J Prosthet Dent 1994; 72: 538-542.

3. Dikbas I, Ozkurt Z, Kazazoglu E. Predoctoral Prosthodontic Curriculum on Removable Partial Dentures: Survey in Turkish Dental Faculties. J Dent Educ 2013; 77: 85-92.

4. Obrez A, Lee DJ, Organ-Boshes A, Chia -Chun Yuan J, Knight GW. A clinically oriented complete denture program for second-year dental students. J Dent Educ 2009; 73: 1194-1201.

5. Henning K, Ey S, Shaw D. Perfectionism, the imposter phenomenon and psychological adjustment in medical, dental, nursing, and pharmacy students. Med Educ 1998; 32: 456-464.

6. Newbury BD, Lowry RJ, Kamali F. The changing patterns ofdrinking, illicitdrug use, stress, anxiety, and depression in dental students in a UK dental school: a longitudinal study. British Dent J 2002; 192: 646-649.

7. Freeman RE. Dental students as operators: emotional reactions. Med Educ 1985; 19: 27-33.

8. Piazza-Waggoner CA, Cohen LL, Kohli K, Taylor BK. Stress management for dental students performing their first pediatric restorative procedure. J Dent Eduo 2003; 67: 542-548.

9. Sukotjo C, Thammasitboon K, Howell H, Karimbux N. Students' perceptions of prosthodontics in a PBL hybrid curriculum. J Prosthodont 2008; 17: 495-501.

10. Curtis DA, Lind SL, Brear S, Finzen FC. The correlation of student performance in preclinical and clinical prosthodontic assessments. J Dent Educ 2007; 71. 365-372.

11. Nikzad S, Azari A, Mahgoli H, Akhoundi N. Effect of a procedural video CD and study guide on the practical fixed prosthodontic performance of Iranian dental students. J Dent Educ 2012; 76: 354-359.

12. Johnsen DC, Lipp MJ, Finkelstein M., Cunningham-Ford MA. Guiding dental student learning and assessing performance in critical thinking with analysis of emerging strategies. J Dent Educ 2012; 76: 1548-1558.

13. Curtis DA, Lind SL, Dellinges M, Setia G, Finzen FC. Dental students' self-assessment of preclinical examinations. J Dent Educ 2008; 72: 265-277.

14. Simon FA, Aschenbrener CA. Undergraduate medical education accreditation as a driver of lifelong learning. J
Contin Educ Health 2005; 25: 157-161.

15. Cohen SN, Silvestri AR. Evaluation of describing and grading preclinical technical exercises. J Dent Educ, 1980; 44: 547-549.

16. Feil PH, Reed T. The effect of knowledge of the desired outcome on dental motor performance. J Dent Educ 1988; 52: 198-201.

17. Ferguson $M B$, Sobel $M$, Niederman R. Preclinical restorative training. J Dent Educ 2002; 66: 1159-1162.

18. Ozkurt Z, Dikbas I, Kazazoğlu E. Pre-doctoral Prosthodontic Clinical Curriculum for Complete Dentures: Survey in Turkish Dental Schools. J Dent Educ 2013; 77: 93-98. 